\title{
A comparative study on dietary patterns and nutritional status among working and non-working women of Keonjhar city
}

Received: 10.08.2016; Revised: 25.09.2016; Accepted: 10.10.2016

Author for Correspondence :

\section{VIJAYETA PRIYADARSHINI}

Department of Home Science, Govt. Women's College, KEONJHAR (ODISHA) INDIA

Email : vijayeta.priyadarshini@ gmail.com
ABSTRACT : The purposes of this study were to study the dietary patterns and health and nutritional status of the working and non-working women in Keonjhar city. A total of 55 working women and 55 non-working women in between the age of 25 to 40 years were selected randomly and comparison was done between these two groups. Height, Body weight and body mass index (BMI) were taken as variables for measurement of health and nutritional status of the respondents. Result shows that non-working women group were superior in weight and BMI than working women. As per the dietary pattern the observed value of $\mathrm{X}^{2}$ was found to be significant at $\mathrm{p}$ $<0.05$ in case of intake of major meal of the day, consumption of snacks per day and taking meal outside criteria.

KEY WORDS: Dietary pattern, Nutritional status, Health, Working women, Non-working women

- HOW TO CITE THIS PAPER : Priyadarshini, Vijayeta (2016). A comparative study on dietary patterns and nutritional status among working and non-working women of Keonjhar city. Asian J. Home Sci., 11 (2) : 320-326, DOI: 10.15740/HAS/AJHS/11.2/320-326. 